\title{
Nature of Inheritance of Yield and its Related Traits in Dual Purpose Sorghum [Sorghum bicolor (L.) Moench]
}

\author{
B. L. Meena ${ }^{1 *}$, B. R. Ranwah ${ }^{2}$, H. S. Meena ${ }^{1}$ and M. D. Meena ${ }^{1}$ \\ ${ }^{1}$ ICAR-DRMR, Bharatpur Rajasthan-321303, India \\ ${ }^{2}$ MPUAT, Rajasthan College of Agriculture, Udaipur Rajasthan -313001, India \\ *Corresponding author
}

\section{A B S T R A C T}

\begin{tabular}{l}
\hline Ke y w or d s \\
$\begin{array}{l}\text { Sorghum } \\
\text { [Sorghum bicolor } \\
\text { (L.) Moench] }\end{array}$ \\
\hline Article Info \\
$\begin{array}{l}\text { Accepted: } \\
10 \text { August } 2020 \\
\text { Available Online: } \\
10 \text { September } 2020\end{array}$ \\
\hline
\end{tabular}

This experiment was having two sub experiments viz., cross SPV245 x SPV 1822 (A X C) and SPV $1430 \times$ SPV 1822 (B X C). Test crosses for this experiment was obtained by crossing the $10 \mathrm{MS}$ lines with both the parents and their $\mathrm{F}_{1}$ 's for both the sets. In this way the each sub experiment was having 30 hybrids. Both the sub experiments were conducted in RBD with three replications following the $45 \mathrm{~cm}$ between rows and $10 \mathrm{~cm}$ between plants spacing. In present investigation difference between testers in line in both sets of TTC were significant. The total and " $\mathrm{j}+\mathrm{l}$ " type of epistasis were significant for all the characters in most of the sets. Whereas, " $i$ " type epistasis was significant for 4,3 and 8 characters in set SPV $245 \times$ SPV 1430, SPV $245 \times$ SPV 1822 and SPV $1430 \times$ SPV 1822 , respectively. This was on account of significance of epistasis in one or other lines. After dropping the epistatic lines the unbiased $\mathrm{D}$ and $\mathrm{H}$ were estimated. Both $\mathrm{D}$ and $\mathrm{H}$ were significant for all the characters except additive variance (D) for green fodder yield and seed index in set SPV 1430 x SPV 1822, days to maturity in set SPV 245 x SPV 1430 and ear head lenght in set SPV 245 x SPV 1822.

\section{Introduction}

Sorghum bicolor (L.) Moench $(2 \mathrm{n}=20)$, family poaceae is one of the most important crops in the world because of its adaptation to a wide range of ecological conditions, suitability for low input cultivation and diverse uses (Doggett, 1988). Sorghum occupies fifth position after wheat, rice, maize and barley at world level, both in area and production. The crop is widely grown for food, feed, fodder, forage and fuel in the semi-arid tropics (SAT) of Asia, Africa, America and Australia. It occupies $58.20 \mathrm{~m}$ ha area in the world with an annual grain production of $68.87 \mathrm{~m}$ tones and productivity of $1535 \mathrm{~kg} / \mathrm{ha}$ (FAO, 2015). In India, it covers about $5.82 \mathrm{~m}$ ha with an annual grain production of $5.39 \mathrm{~m}$ tonnes and productivity of $926 \mathrm{~kg} / \mathrm{ha}$ (FAO, 2015). India is largest producer of sorghum in the world (FAO, 2015). The major sorghum growing states in India are Maharashtra, Karnataka, Madhya Pradesh, Andhra Pradesh, Rajasthan, Tamil Nadu, Uttar Pradesh and Gujarat. Area under sorghum reduced a large since independence. Area under sorghum reduced from $17.40 \mathrm{~m}$ hectares (1970-71) to $5.82 \mathrm{~m}$ hectares (2014- 
15). But production increased from $8.1 \mathrm{~m}$ tones (1970-71) to $5.39 \mathrm{~m}$ tones (2014-15).

In Rajasthan, it is grown for dual purpose with high emphasis on fodder, mainly it is grown under sub-marginal agro-climatic and edaphic conditions which, is characterized by low soil fertility and recurring moisture stress. It occupies an area of about 6.61 lakh hectares with 5.05 lakh tones production in the year 2015. The productivity of sorghum in the state is $763 \mathrm{~kg} / \mathrm{ha}$ (Anonymous, 2015). Low productivity is due to cultivation of sorghum on marginal soil, low inputs and more emphasis on fodder. Being $\mathrm{C}_{4}$ sorghum has great potentiality. Its grain yield productivity in rice fellow fields is up to $80 \mathrm{q} \mathrm{ha}^{-1}$. Area under sorghum reduced a large since independence. Area under sorghum reduced from 10.08 lakh hectares (1970-71) to 6.61 lakh hectares (2015). But production increased from 3.20 lakh tones (1970-71) to 5.05 lakh tones (2015). The reduction in the area is mainly due to replacement of sorghum by more remunerating crops like maize, soybean etc. The stability in the production is on account of availability of high yielding varieties and inputs. Sorghum green fodder is one of the cheapest sources of feed for milch, meat and draft animals. Among the cereals, sorghum plays an important role being grain cum fodder crop. Mainly three type of sorghum is cultivated i.e. grain, fodder and multicut sorghum. Grain sorghum is having low plant height and high harvest index, fodder sorghum having tall plants and multicut is leafy, thin stem and more tillering ability. The multicut sorghum fulfills the requirement of green fodder particularly during summer but needs irrigation facilities.

The grain and fodder sorghum mainly cultivated in rainy season in north India and in both rainy and post rainy in south India. In Rajasthan area under grain sorghum is very low. Mainly fodder sorghum is cultivated in Rajasthan during rainy season and that too without bird watching.
Sorghum is predominantly self-pollinated crop endowed with a wide range of genetic variability due to its wide range of adaption and free gene exchange among various races. Careful selection of parents for hybridization is a key of success in any breeding programme. Some idea about the usefulness of parents may be obtained from their per se performance, but the knowledge of nature of inheritance is essential for success of breeding programme. Breeding for wide adaption is another important aspect in genetic improvement of crop plants. It is well known that a specific genotype may not exhibit the same performance in all the environments nor all the genotypes respond alike to a specific environment. Such differential response of genotypes to varying environmental conditions reduces the agricultural production. Therefore, knowledge about behavior of genotypes in different environment is essential for their recommendation and their further use in breeding programme. For this, it is desirable to see the impact of various environments on the sorghum genotypes in order to identify the parents and /or crosses for further utilization in breeding programme. $\mathrm{L} \times \mathrm{T}$ for combining ability and TTC for working out the nature of inheritance are most appropriate mating designs for the type of genetic material used in present investigation and information to be derived. Maintenance of plant population in per unit area is very difficult. Buffering ability of the genotypes is the only way to cope up with the available space. Therefore, breeding for buffering ability is another important aspect in genetic improvement of crop plants. Development of such a hybrid/variety, which gives a constant and desirable performance over wide range of spacing, is needed. For this, it is desirable to see the impact of various spacing on the yield of sorghum genotypes and identification of genotypes having buffering ability.The information on the nature and magnitude of 
gene action is important in understanding the genetic potential of population and to decide the breeding procedure to be adopted in given population. Among the available mating designs Triple Test Cross (TTC) is the most efficient mating design provide information about epistasis. Present investigation entitled "Nature of inheritance of yield and yield related traits in dual purpose sorghum [Sorghum bicolor (L.) Moench]" has been planned and genotypes were evaluated during kharif, 2014 and kharif, 2015 at Instructional Farm, Rajasthan college of Agriculture, Udaipur with the following objectives.

\section{Materials and Methods}

The present investigation entitled "Nature of inheritance of yield and yield related traits in dual purpose sorghum [Sorghum bicolor (L.) Moench]" was conducted at Instructional farm, Rajasthan College of Agriculture, Udaipur during kharif 2014 and kharif 2015. To met out the objectives. The study was completed through Triple test cross mating design.

\section{Experimental site and condition}

Geographically Instructional Farm is situated at $24^{\circ}-35^{\prime}$ North latitude and $73^{\circ}-42^{\prime}$ East longitude. The elevation of institution farm is 582.17 meters above mean sea level. The climatic conditions of the area represent subtropical condition with humid climate. The soil of experimental fields was clay loam, deep, well drained, alluvial in origin and having fairly good moisture holding capacity.

\section{Experimental material}

On the basis of days to flowering and suitability for dual purpose 36 lines were received from ICRISAT. After evaluation at this station 10 lines were identified on the basis of nicking of flowering. Three testers were identified on the basis of availability of restorer gene and past performance. Checks CSV 23, CSV 27 and CSH 25 were national checks in coordinated trials.

In Triple Test Cross experiment, the three testers viz., SPV 245 (A), SPV 1430 (B) and SPV 1822 (C) were crossed in all possible combination during kharif 2014 to obtained three $\mathrm{F}_{1}$, i.e. $\mathrm{A} \mathrm{X} \mathrm{B}, \mathrm{A} \times \mathrm{C}$ and $\mathrm{B} \times \mathrm{C}$ at Udaipur. In the next season all 10 lines were crossed with three testers i.e. $\mathrm{T}_{1}, \mathrm{~T}_{2}$ and $\mathrm{F}_{1}\left(\mathrm{~T}_{1}\right.$ $\times \mathrm{T}_{2}$ ) of all the three cross (set) at Warangal. In this way 30 hybrids were obtained for each set (cross).

\section{Experimental design}

\section{Triple Test Cross}

This experiment was having two sub experiments viz., cross SPV 245 x SPV 1430 (A X B) and SPV245 x SPV 1822 (A X C). Test crosses for this experiment was obtained by crossing the $10 \mathrm{MS}$ lines (ICSA 29003(L $\left.\mathrm{L}_{1}\right)$, ICSA $29004\left(\mathrm{~L}_{2}\right)$, ICSA 29006 $\left(\mathrm{L}_{3}\right)$, ICSA $29010\left(\mathrm{~L}_{4}\right)$, ICSA 29011(L5), ICSA $29012\left(\mathrm{~L}_{6}\right)$, ICSA $29013\left(\mathrm{~L}_{7}\right)$, ICSA $29014\left(\mathrm{~L}_{8}\right)$, ICSA $29015\left(\mathrm{~L}_{9}\right)$ and ICSA 29016 (L 10)) with both the parents and their $\mathrm{F}_{1}$ 's for both the sets. In this way each sub experiment was having 30 hybrids. All the three sub experiments were conducted in RBD with three replications following the 45 $\mathrm{cm}$ between rows and $10 \mathrm{~cm}$ between plants spacing. On both the side of all the experiments two non experimental rows were planted to eliminate the border effects. The other agronomical practices were used as per the recommendation of this agro climatic zone to raise the healthy crop. The NPK fertilizer was applied at the rate of 80:40:00 $\mathrm{kg} / \mathrm{ha}$. The total amount of phosphatic fertilizer and half of the nitrogenous fertilizer was applied as basal dose using DAP and Urea and rest of the nitrogen was applied 
through Urea in two equal doses, one at kneehigh stage and another at flowering stage of the crop.

\section{Traits under investigation}

Observations were recorded on following 14 characters. To record different observation five competitive plants in each plot were tagged at random. Days to $50 \%$ flowering, days to maturity, plant height $(\mathrm{cm})$, green fodder yield ( $\left.\mathrm{q} \mathrm{ha}{ }^{-1}\right)$, dry fodder yield $\left(\mathrm{q} \mathrm{ha}^{-1}\right)$, ear head length $(\mathrm{cm})$, number of primaries per plant, number of seeds per primaries, seed index, harvest index $(\%)$, grain yield $\left(\mathrm{q} \mathrm{ha}^{-1}\right)$, Protein content in fodder $(\%)$ and protein content in grain $(\%)$.

\section{Statistical analysis}

Plot means of all the characters were subjected to various statistical analysis except stay greenness. The statistical analysis followed for experiment were as follows:

\section{Triple test cross analysis}

Triple test cross analysis was performed according to the method proposed by Ketata et. al. (1976) for detecting epistasis which is essentially the same as that of Bauman (1959). This method employs a set of lines crossed to testers $T_{1}, T_{2}$ and $T_{3}$ where $T_{3}$ is the $F_{1}$ of $T_{1} \times T_{2}$.

\section{Detection of epistasis}

The procedure put forth by Kearsey and Jinks (1968) was followed to detect the presence of epistasis. The procedure involves a set of lines, crossed to three $T_{1}, T_{2}$ and $T_{3}, T_{3}$ being the $\mathrm{F}_{1}$ of $\mathrm{T}_{1} \times \mathrm{T}_{2}$. Ketata et al., (1976) suggested the use of different varieties instead of $\mathrm{F}_{2}$ plants. This test is based on following model.

$\mathrm{L}_{\mathrm{ik}}=\mathrm{X}_{\mathrm{i} 1 \mathrm{k}}+\mathrm{X}_{\mathrm{i} 2 \mathrm{k}}-2 \mathrm{X}_{\mathrm{i} 3 \mathrm{k}}$
Where, $\mathrm{L}_{\mathrm{ik}}$ is the epistasis in $\mathrm{i}^{\text {th }}$ lines and $\mathrm{k}^{\text {th }}$ block/condition, $X_{i 1 k}, X_{i 2 k}$ and $X_{i 3 k}$ are the value of cross between $i^{\text {th }}$ line and $1^{\text {st }}, 2^{\text {nd }}$ and $3^{\text {rd }}$ tester in $\mathrm{k}$ the block/ condition. This value was calculated for each line (variety) in each replication and over the replications.

Significance of epistasis for each line was tested by using t test as follows

$\mathrm{t}_{[\mathrm{g}-1)(\mathrm{r}-1)]}=\frac{\mathrm{x}}{\mathrm{SE}}$

Where,

$x=\overline{L_{1}}+\overline{L_{2}}-2 \overline{L_{3}}$

$\mathrm{SE}=\sqrt{\frac{6 M S E}{r}}$

MSE $=\sum_{i=1}^{\mathrm{t}} \sum_{j=1}^{y} x_{i j}^{2}-\sum_{i=1}^{\mathrm{t}}\left(\sum_{j=1}^{y} x_{i j}\right)^{2} / r-\sum_{j=1}^{y}\left(\sum_{i=1}^{\mathrm{t}} x_{i j}\right)^{2} / t+\left(\sum_{j=1}^{y} \sum_{i=1}^{\mathrm{t}} x_{i j}\right)^{2} / t r$

Where,

$\mathrm{x}_{\mathrm{ij}}=$ Value of $\mathrm{i}^{\text {th }}$ genotype in $\mathrm{j}^{\text {th }}$ replication

$\mathrm{r}$ and $\mathrm{t}=$ Number of replications and genotype, respectively

$\overline{L_{1}}, \overline{L_{2}}$ and $\overline{L_{1}}=$ mean of cross between $P_{1} \times V_{1}, P_{2} \times V_{1}$ and $\left(P_{1} \times P_{2}\right) \times V_{1}$,respectidly

$\mathrm{V}_{\mathrm{i}}=\mathrm{i}^{\text {th }}$ variety used as line in crossing programme.

\section{Estimation of ' $D$ ' and ' $H$ ' Components}

For unbiased estimation of $\mathrm{D}$ and $\mathrm{H}$ components i.e. in the absence of epistasis, only those lines were used for estimation of these components epistasis was absent.

\section{D component}

To estimate the additive variance (D) the sum of $\mathrm{L}_{1 \mathrm{i}}+\mathrm{L}_{2 \mathrm{i}}$ was worked out for each variety in each replication and over the replications where epistasis was not significant. 
Significance of additive variance (D) was tested using $\mathrm{F}$ test

$\sigma^{2} \mathrm{~s}=\left(\mathrm{MS}_{2}-\mathrm{MS}_{3}\right) / 2 \mathrm{r}$

$\mathrm{D}=8 \sigma^{2} \mathrm{~s}$.

\section{'H' component}

To estimate the $\mathrm{H}$ components (dominance variance) differences between cross of $i^{\text {th }}$ lines and tester $T_{1}$ and $T_{2}$ were used. Only those values were conderd which were lacking the epistasis. The ANOVA was calculated as per Table 1.

Significance of dominance variance $(\mathrm{H})$ was tested using $\mathrm{F}$ test. The value of $\mathrm{H}$ was calculated as follows:

$\sigma^{2} \mathrm{~s}=\left(\mathrm{MS}_{2}-\mathrm{MS}_{3}\right) / 2 \mathrm{r}$

$\mathrm{H}=8 \sigma^{2} \mathrm{~s}$.

The negative value was considered zero.

The degree of dominance was calculated only for those characters where both $\mathrm{D}$ and $\mathrm{H}$ were present. Formula used for this was as follows:

$=\sqrt{(H / D)}$

\section{Direction of dominance}

To determine the direction of dominance correlation between sums $\left(\mathrm{S}_{\mathrm{i}}\right)$ and differences $\left(D_{i}\right)$ was worked out.

$r_{S D}=\frac{\sum_{i=1}^{l} S_{i} D_{i}-\sum_{i=1}^{l} S_{i} \sum_{i=1}^{l} D_{i}}{\sqrt{\left[\sum_{i=1}^{l} S_{i}^{2}-\left(\sum_{i=1}^{l} S_{i}\right)^{2} / l^{X} \sum_{i=1}^{l} D_{i}^{2}-\left(\sum_{i=1}^{l} D_{i}\right)^{2} / l\right]}}$

Significance was tested using ' $\mathrm{t}$ ' test

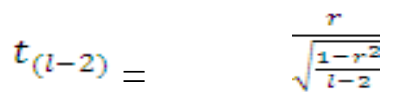

The negative and significant value of ' $r$ ' suggested that increasing genes were dominant and vice-versa.
Where $S_{i}$ and $D_{i}$ is the sums and difference between crosses obtained by crossing $i^{\text {th }}$ line with $\mathrm{T}_{1}$ and $\mathrm{T}_{2}$ testers. And $\mathrm{r}$ and $l$ are the number of replications and lines respectively.

\section{Results and Discussion}

The experimental results of present investigation entitled "Nature of inheritance of yield and yield related traits in dual purpose sorghum [Sorghum bicolor (L.) Moench]" are presented as

\section{Analysis of variance}

The analysis of variance for different characters indicated significant differences between lines for all the characters in both the crosses (SPV 245 X SPV 1822 and SPV 1430 $x$ SPV 1822) except harvest index in cross SPV 1430 x SPV 1822 (Table 1).

\section{Nature of inheritance}

Average degree of dominance $(\sqrt{(\mu / D)})$ were greater than unity for grain yield (1.37), harvest index (1.36), plant height (1.17) and seed index (1.16). For rest of the characters it was less than unity (Table 4).

The direction of dominance was positive i.e. negative correlation differences sums and differences between $\mathrm{L}_{1}$ and $\mathrm{L}_{2}$ for days to maturity, plant height, dry fodder yield, number of seeds per primary, protein content in grain and protein content in fodder where as direction of dominance was negative for days to $50 \%$ flowering, green fodder yield, ear head length, number of primaries per plant, seed index, harvest index and grain yield.

\section{Set 1- SPV 245 x SPV 1822}

The analysis of variance for detection of epistasis for thirteen characters is given in 
Table 2. The effect of line in epistasis was significant in 33 combinations out of 130. All the lines were having epistasis for one or other characters.

The numbers of characters ranged from $1\left(\mathrm{~L}_{8}\right)$ to $6\left(\mathrm{~L}_{2} \& \mathrm{~L}_{3}\right)$. For ear head length and protein content in grain none was having significant epistasis. Whereas for plant height $\left(\mathrm{L}_{3}\right)$ and harvest index $\left(\mathrm{L}_{4}\right)$ only one line was having epistasis. In rest of the characters it ranged from 2 to 6 (Table 3).

Magnitude of D and $\mathrm{H}$ increased in 7 and 5 characters, remain constant in 2 characters and decreased in 4 and 6 characters. Consistency was observed only in those characters where none of the line was epistatic (Table 5).

Total epistasis was significant for days to $50 \%$ flowering, days to maturity, plant height, green fodder yield, dry fodder yield, number of primaries per plant, number of seeds per primary, seed index, grain yield, protein content in grain and protein content in fodder. All these characters also had significant ' $\mathrm{j}+$ l'epistasis, except days to $50 \%$ flowering, where as ' $i$ ' is significant for dry fodder yield, ear head length and protein content in grain (Table 2).

The direction of dominance was positive i.e. negative correlation between sums and differences between $L_{1}$ and $L_{2}$ for dry fodder yield, number of seeds per primary, protein content in grain and protein content in fodder where as direction of dominance was negative for days to $50 \%$ flowering, days to maturity, plant height, green fodder yield, ear head length, number of primaries per plant, seed index, harvest index and grain yield (Table 2).

\section{Cross 2 - SPV 1430 x SPV 1822}

Total epistasis was significant for days to 50 $\%$ flowering, days to maturity, plant height, green fodder yield, dry fodder yield, ear head length, number of primaries per plant, number of seeds per primary, harvest index, grain yield, protein content in grain and protein content in fodder. All these characters also had significant of ' $j+1$ ' epistasis, where as ' $i$ ' was significant for days to $50 \%$ flowering, days to maturity, green fodder yield, dry fodder yield, ear head length, grain yield, protein content in grain and protein content in fodder (Table 2)

In this cross out of 130 (10 lines $\mathrm{x} 13$ characters) combinations 60 had significant epistasis (Table 3). All the lines having significant epistasis for one or other characters. It was ranged from $1\left(\mathrm{~L}_{2}\right)$ to $9\left(\mathrm{~L}_{3}\right.$ $\left.\& \mathrm{~L}_{4}\right)$ characters. Similarly, all the characters having significant epistasis in one or more lines except ear head length where epistasis was not significant for any of the lines (Table $3)$. In rest of the characters epistastic lines were ranged from 3 (harvest index) to 7 (days to maturity and green fodder yield). After unbiased estimations of $\mathrm{D}$ and $\mathrm{H}$, their magnitude was increased in 7 and 3 characters, remains constant in 1 character and decreased in 5 and 9 characters. The unbiased estimate of $\mathrm{D}$ and $\mathrm{H}$ was significant for all the characters except D for Green fodder yield and seed index and $\mathrm{H}$ for days to flowering, plant height and ear head length (Table 4). The average degree of dominance $(\sqrt{(H / D)})$ was more than unity for dry fodder yield (1.44), seed index (1.40), harvest index (1.06) and grain yield (1.01) whereas for rest of the characters it was less than unity. The direction of dominance was positive i.e. negative correlation differences sums and differences between $L_{1}$ and $L_{2}$ for days to maturity, green fodder yield, number of seeds per primary, grain yield and protein content in fodder where as direction of dominance was negative for days to $50 \%$ flowering, plant height, dry fodder yield, ear head length, number of primaries per plant, seed index, harvest index and protein content in grain 
(Table 2). Sorghum is a very important multi use crop providing food, feed, fodder, forage, fuel etc. It is an energy efficient $\mathrm{C}_{4}$ plant but, mainly cultivated on marginal soil under rain fed condition with low inputs. Considerable progress has been made in developing improved cultivars of grain type. In recent past the importance of dual purpose was realized with a wider acceptance of such genotypes.

Table.1 ANOVA (MS) for different characters

\begin{tabular}{|c|c|c|c|c|c|}
\hline \multirow[t]{2}{*}{ S. No. } & Characters & Cross & Rep/Lines & TC/Lines & Error \\
\hline & & & [20] & [20] & [40] \\
\hline \multirow[t]{2}{*}{1} & Days to $50 \%$ flowering & $\mathrm{A} \times \mathrm{C}$ & 13.99 & $46.42 * *$ & 13.96 \\
\hline & & $\mathrm{B} \times \mathrm{C}$ & 5.52 & $85.29 * *$ & 7.34 \\
\hline \multirow[t]{2}{*}{2} & Days to maturity & $\mathrm{A} \times \mathrm{C}$ & 3.13 & $14.80 * *$ & 2.37 \\
\hline & & $\mathrm{B} \times \mathrm{C}$ & 1.43 & $21.40 * *$ & 1.70 \\
\hline \multirow[t]{2}{*}{3} & Plant height & $\mathrm{A} \times \mathrm{C}$ & 286.93 & $1727.17 * *$ & 229.82 \\
\hline & & $\mathrm{B} \times \mathrm{C}$ & 166.56 & $1548.36^{* *}$ & 219.17 \\
\hline \multirow[t]{2}{*}{4} & Green fodder yield & $\mathrm{A} \times \mathrm{C}$ & 1767.38 & $39309.24 * *$ & 1055.26 \\
\hline & & $\mathrm{B} \times \mathrm{C}$ & 1650.19 & $41575.79 * *$ & 1138.16 \\
\hline \multirow[t]{2}{*}{5} & Dry fodder yield & $\mathrm{A} \times \mathrm{C}$ & 350.50 & $11047.60 * *$ & 275.97 \\
\hline & & $\mathrm{B} \times \mathrm{C}$ & 265.20 & $12455.90^{* *}$ & 319.15 \\
\hline \multirow[t]{2}{*}{6} & Ear head length & $\mathrm{A} \times \mathrm{C}$ & 7.49 & $17.22 *$ & 8.52 \\
\hline & & $\mathrm{B} \times \mathrm{C}$ & 4.19 & $26.99 * *$ & 7.66 \\
\hline \multirow[t]{2}{*}{7} & Number of primaries per plant & $\mathrm{A} \times \mathrm{C}$ & $46.19 *$ & $180.19 * *$ & 23.62 \\
\hline & & $\mathrm{B} \times \mathrm{C}$ & $15.34 *$ & $342.41 * *$ & 44.73 \\
\hline \multirow[t]{2}{*}{8} & Number of seeds per primary & $\mathrm{A} \times \mathrm{C}$ & 42.98 & $357.04 * *$ & 64.29 \\
\hline & & $\mathrm{B} \times \mathrm{C}$ & 27.33 & $1233.33 * *$ & 53.12 \\
\hline \multirow[t]{2}{*}{9} & Seed index & $\mathrm{A} \times \mathrm{C}$ & 0.07 & $0.25 * *$ & 0.05 \\
\hline & & $\mathrm{B} \times \mathrm{C}$ & 0.05 & $0.16^{*}$ & 0.07 \\
\hline \multirow[t]{2}{*}{10} & Harvest index & $\mathrm{A} \times \mathrm{C}$ & 8.01 & 13.77 & 7.97 \\
\hline & & $\mathrm{B} \times \mathrm{C}$ & 18.17 & $220.47 * *$ & 15.62 \\
\hline \multirow[t]{2}{*}{11} & Grain yield & $\mathrm{A} \times \mathrm{C}$ & 73.74 & $1599.14 * *$ & 66.93 \\
\hline & & $\mathrm{B} \times \mathrm{C}$ & 114.64 & $3610.04 * *$ & 93.89 \\
\hline \multirow[t]{2}{*}{12} & Protein content in grain & $\mathrm{A} \times \mathrm{C}$ & 0.23 & $10.15^{* *}$ & 0.21 \\
\hline & & $\mathrm{B} \times \mathrm{C}$ & 0.03 & $9.64 * *$ & 0.02 \\
\hline \multirow[t]{2}{*}{13} & Protein content in fodder & $\mathrm{A} \times \mathrm{C}$ & $0.07 * *$ & $1.84 * *$ & 0.03 \\
\hline & & $\mathrm{B} \times \mathrm{C}$ & 0.01 & $1.83 * *$ & 0.01 \\
\hline
\end{tabular}

[] Degrees of freedom

$*$, ** Significant at 5 and 1 per cent level of significance 
Table.2 ANOVA for epistasis and correlation between per se and direction of dominance

\begin{tabular}{|c|c|c|c|c|c|c|c|c|c|}
\hline SN & Charactar & Cross & $\mathbf{i}$ & $j+1$ & Total & i x B & j+l x B & TEpixB & $\mathbf{r}$ \\
\hline & & & [1] & [9] & {$[10]$} & {$[2]$} & [18] & [20] & {$[8]$} \\
\hline \multirow[t]{2}{*}{1} & \multirow{2}{*}{$\begin{array}{l}\text { Days to } 50 \% \\
\text { flowering }\end{array}$} & $A \times C$ & 907.50 & 156.91 & $231.97 *$ & 79.30 & 83.71 & 83.27 & $0.35^{*}$ \\
\hline & & $\mathrm{B} \times \mathrm{C}$ & $3328.53 *$ & $300.24 * *$ & $603.07 * *$ & 122.63 & 47.45 & 54.97 & $0.54 *$ \\
\hline \multirow[t]{2}{*}{2} & \multirow{2}{*}{$\begin{array}{l}\text { Days to } \\
\text { maturity }\end{array}$} & $A \times C$ & 710.53 & $28.83^{*}$ & $97.00 * *$ & 57.43 & 8.62 & 13.50 & $0.05^{*}$ \\
\hline & & B x C & $1190.70 *$ & $72.92^{* *}$ & $184.70^{* * *}$ & 4.30 & 10.74 & 10.10 & $-0.13^{*}$ \\
\hline \multirow[t]{2}{*}{3} & Plant height & $A \times C$ & 374.53 & $11746.61^{* *}$ & $10609.40^{* *}$ & 1158.63 & 795.82 & 832.10 & $-0.74 *$ \\
\hline & & $\mathrm{B} \times \mathrm{C}$ & 37949.63 & $6432.00 * *$ & $9583.77 * *$ & 2816.43 & 1694.91 & 1807.07 & $0.22 *$ \\
\hline \multirow[t]{2}{*}{4} & \multirow{2}{*}{$\begin{array}{l}\text { Green fodder } \\
\text { yield }\end{array}$} & $A \times C$ & 5713.20 & $358132.01 * *$ & $322890.13^{* *}$ & 2770.00 & 8309.59 & 7755.63 & 0.68 \\
\hline & & $\mathrm{B} \times \mathrm{C}$ & $617767.50 *$ & $144282.46^{* * *}$ & $191630.97 * *$ & 2342.10 & 10690.29 & 9855.47 & $-0.32 *$ \\
\hline \multirow[t]{2}{*}{5} & \multirow{2}{*}{$\begin{array}{l}\text { Dry fodder } \\
\text { yield }\end{array}$} & $A \times C$ & $51750.53^{*}$ & $84321.27 * *$ & $81064.20^{* *}$ & 1619.43 & 1539.95 & 1547.90 & $-0.23^{*}$ \\
\hline & & B x C & $49369.63^{*}$ & $78720.60^{* *}$ & $75785.50 * *$ & 1538.23 & 1705.20 & 1688.50 & $0.21 *$ \\
\hline \multirow[t]{2}{*}{6} & $\begin{array}{l}\text { Ear head } \\
\text { length }\end{array}$ & $A \times C$ & $64.53^{*}$ & 31.35 & 34.67 & 1.63 & 59.34 & 53.57 & $0.48 *$ \\
\hline & & B x C & $1216.03 *$ & $129.74 *$ & $238.37 * *$ & 52.03 & 46.29 & 46.87 & $0.30^{*}$ \\
\hline \multirow[t]{2}{*}{7} & \multirow{2}{*}{$\begin{array}{l}\text { Number of } \\
\text { primaries/plant }\end{array}$} & $A \times C$ & 276.03 & $1778.85^{* *}$ & $1628.57 * *$ & 119.63 & 205.00 & 196.47 & $0.05^{*}$ \\
\hline & & $\mathrm{B} \times \mathrm{C}$ & 229.63 & $1882.97 * *$ & $1717.63 * *$ & 266.13 & 277.47 & 276.33 & $0.59 *$ \\
\hline \multirow[t]{2}{*}{8} & \multirow{2}{*}{$\begin{array}{l}\text { Number of } \\
\text { seeds / } \\
\text { primary }\end{array}$} & $\mathrm{A} \times \mathrm{C}$ & 367.50 & $2131.65^{* *}$ & $1955.23 * *$ & 529.60 & 507.64 & 509.83 & $-0.47^{*}$ \\
\hline & & $\mathrm{B} \times \mathrm{C}$ & 472.03 & $6543.00 * *$ & $5935.90 * *$ & 299.43 & 233.29 & 239.90 & $-0.65^{*}$ \\
\hline \multirow[t]{2}{*}{9} & Seed index & $A \times C$ & 0.39 & $1.85 * *$ & $1.71 * *$ & $0.62 *$ & 0.17 & 0.22 & $0.04^{*}$ \\
\hline & & $\mathrm{B} \times \mathrm{C}$ & 8.41 & 0.24 & 1.06 & 3.18 & 0.30 & 0.58 & $0.26^{*}$ \\
\hline \multirow[t]{2}{*}{10} & Harvest index & $A \times C$ & 58.02 & 53.64 & 54.08 & 40.44 & 31.93 & 32.79 & $0.12^{*}$ \\
\hline & & $\mathrm{B} \times \mathrm{C}$ & 861.03 & $1283.06^{* *}$ & $1240.86^{* *}$ & 49.89 & 95.44 & 90.89 & $0.11^{*}$ \\
\hline \multirow[t]{2}{*}{11} & Grain yield & $A \times C$ & 2881.20 & $14233.13 * *$ & $13097.93 * *$ & 310.00 & 368.59 & 362.73 & $0.33^{*}$ \\
\hline & & $\mathrm{B} \times \mathrm{C}$ & $6482.70 *$ & $23154.40 * *$ & $21487.23 * *$ & 87.30 & 606.67 & 554.73 & $-0.30^{*}$ \\
\hline \multirow[t]{2}{*}{12} & \multirow{2}{*}{$\begin{array}{l}\text { Protein } \\
\text { content in } \\
\text { grain }\end{array}$} & $A \times C$ & $549.72 *$ & $48.13 * *$ & $98.29 * *$ & 1.72 & 2.38 & 2.32 & $-0.64 *$ \\
\hline & & $\mathrm{B} \times \mathrm{C}$ & $83.53^{* *}$ & $70.72 * *$ & $72.00 * *$ & 0.17 & 0.14 & 0.15 & $0.29^{*}$ \\
\hline \multirow[t]{2}{*}{13} & \multirow{2}{*}{$\begin{array}{l}\text { Protein } \\
\text { content in } \\
\text { fodder }\end{array}$} & $A \times C$ & 1.71 & $17.94 * *$ & $16.32 * *$ & $0.92 * *$ & 0.12 & 0.20 & $-0.49^{*}$ \\
\hline & & $\mathrm{B} \times \mathrm{C}$ & $2.34 *$ & $17.05^{* *}$ & $15.58 * *$ & 0.01 & 0.06 & 0.05 & $-0.40^{*}$ \\
\hline
\end{tabular}

[] Degrees of freedom

$*$,** Significant at 5 and 1 per cent level of significance 
Table.3 Significance of epistasis in individual line in different sets Set- SPV $245 \times$ SPV 1822

\begin{tabular}{|c|c|c|c|c|c|c|c|c|c|c|c|c|c|}
\hline Line & $\begin{array}{c}\text { Days to } \\
50 \% \\
\text { flowering }\end{array}$ & $\begin{array}{l}\text { Days to } \\
\text { maturity }\end{array}$ & $\begin{array}{c}\text { Plant } \\
\text { height }\end{array}$ & $\begin{array}{c}\text { Green } \\
\text { fodder } \\
\text { yield }\end{array}$ & $\begin{array}{c}\text { Dry } \\
\text { fodder } \\
\text { yield }\end{array}$ & $\begin{array}{c}\text { Ear } \\
\text { head } \\
\text { length }\end{array}$ & $\begin{array}{c}\text { Number of } \\
\text { primaries } \\
\text { per plant }\end{array}$ & $\begin{array}{c}\text { Number } \\
\text { of seeds } \\
\text { per } \\
\text { primary }\end{array}$ & $\begin{array}{l}\text { Seed } \\
\text { index }\end{array}$ & $\begin{array}{c}\text { Harvest } \\
\text { index }\end{array}$ & $\begin{array}{c}\text { Grain } \\
\text { yield }\end{array}$ & $\begin{array}{l}\text { Protein } \\
\text { content } \\
\text { in grain }\end{array}$ & $\begin{array}{l}\text { Protein } \\
\text { content } \\
\text { in } \\
\text { fodder }\end{array}$ \\
\hline L1 & & & & 1 & 1 & & 1 & & & & & & \\
\hline L2 & 1 & 1 & & 1 & 1 & & & 1 & & & 1 & & \\
\hline L3 & & & 1 & 1 & 1 & & 1 & & 1 & & 1 & & \\
\hline L4 & & 1 & & & 1 & & & & & 1 & 1 & & \\
\hline L5 & & & & & & & 1 & 1 & & & & & 1 \\
\hline L6 & & 1 & & & & & & 1 & & & & & \\
\hline L7 & & 1 & & & & & & & 1 & & & & \\
\hline L8 & & & & & & & & & & & & & 1 \\
\hline L9 & 1 & 1 & & & & & & & & & & & 1 \\
\hline L10 & 1 & 1 & & & & & & & & & & & 1 \\
\hline
\end{tabular}

Set- SPV $1430 \times$ SPV 1822

\begin{tabular}{|c|c|c|c|c|c|c|c|c|c|c|c|c|c|}
\hline Line & $\begin{array}{c}\text { Days to } \\
50 \% \\
\text { flowering }\end{array}$ & $\begin{array}{l}\text { Days to } \\
\text { maturity }\end{array}$ & $\begin{array}{c}\text { Plant } \\
\text { height }\end{array}$ & $\begin{array}{c}\text { Green } \\
\text { fodder } \\
\text { yield }\end{array}$ & $\begin{array}{c}\text { Dry } \\
\text { fodder } \\
\text { yield }\end{array}$ & $\begin{array}{c}\text { Ear } \\
\text { head } \\
\text { length }\end{array}$ & $\begin{array}{c}\text { Number of } \\
\text { primaries } \\
\text { per plant }\end{array}$ & $\begin{array}{c}\text { Number of } \\
\text { seeds per } \\
\text { primary }\end{array}$ & $\begin{array}{c}\text { Seed } \\
\text { index }\end{array}$ & $\begin{array}{c}\text { Harvest } \\
\text { index }\end{array}$ & $\begin{array}{c}\text { Grain } \\
\text { yield }\end{array}$ & $\begin{array}{l}\text { Protein } \\
\text { content } \\
\text { in grain }\end{array}$ & $\begin{array}{c}\text { Protein } \\
\text { content in } \\
\text { fodder }\end{array}$ \\
\hline L1 & 1 & & & 1 & 1 & & & & & & 1 & 1 & \\
\hline $\mathbf{L} 2$ & & 1 & & & & & & & & & & & \\
\hline L3 & & 1 & 1 & 1 & 1 & & 1 & 1 & 1 & & 1 & 1 & \\
\hline L4 & & 1 & 1 & 1 & 1 & & & 1 & & 1 & 1 & 1 & 1 \\
\hline L5 & 1 & 1 & 1 & 1 & 1 & & 1 & & 1 & & & & 1 \\
\hline L6 & 1 & 1 & & 1 & 1 & & 1 & & & 1 & 1 & & \\
\hline L7 & 1 & & 1 & & & & & & & 1 & & & \\
\hline L8 & & & 1 & 1 & 1 & & & & & & 1 & 1 & 1 \\
\hline L9 & 1 & 1 & 1 & & & & & 1 & & & & & 1 \\
\hline L10 & 1 & 1 & & 1 & & & & 1 & 1 & & & 1 & 1 \\
\hline
\end{tabular}

1= Significance of epistasis 
Table.4 Additive (D), dominance (H) and degree of dominance (DD) Set- SPV $245 \times$ SPV 1822

\begin{tabular}{|l|l|r|r|l|}
\hline $\mathbf{S N}$ & \multicolumn{1}{|c|}{ Charactar } & \multicolumn{1}{|c|}{ D } & \multicolumn{1}{|c|}{ H } & \multicolumn{1}{|c|}{ DD } \\
\hline $\mathbf{1}$ & Days to 50\% flowering & $367.81 * *$ & 11.05 & 0.17 \\
\hline $\mathbf{2}$ & Days to maturity & $351.78 * *$ & 0.00 & 0.00 \\
\hline $\mathbf{3}$ & Plant height & $3630.56 * *$ & $4480.52 * *$ & 1.11 \\
\hline $\mathbf{4}$ & Green fodder yield & $134389.68 * *$ & $24622.13 * *$ & 0.43 \\
\hline $\mathbf{5}$ & Dry fodder yield & $36693.33 * *$ & $12177.78 * *$ & 0.58 \\
\hline $\mathbf{6}$ & Ear head length & 7.10 & $59.42 *$ & 2.89 \\
\hline $\mathbf{7}$ & Number of primaries per plant & $1188.32 * *$ & $246.73 * *$ & 0.46 \\
\hline $\mathbf{8}$ & Number of seeds per primary & $2052.16 * *$ & $762.63 * *$ & 0.61 \\
\hline $\mathbf{9}$ & Seed index & $0.53 *$ & $0.63 * *$ & 1.09 \\
\hline $\mathbf{1 0}$ & Harvest index & $127.72 * *$ & 33.49 & 0.51 \\
\hline $\mathbf{1 1}$ & Grain yield & $8926.16 * *$ & $2179.17 * *$ & 0.49 \\
\hline $\mathbf{1 2}$ & Protein content in grain & $20.65 * *$ & $10.87 * *$ & 0.73 \\
\hline $\mathbf{1 3}$ & Protein content in fodder & $10.78 * *$ & $3.67 * *$ & 0.58 \\
\hline
\end{tabular}

Set- SPV $1430 \times$ SPV 1822

\begin{tabular}{|l|l|r|r|l|}
\hline $\mathbf{S N}$ & \multicolumn{1}{|c|}{ Character } & \multicolumn{1}{|c|}{$\mathbf{D}$} & \multicolumn{1}{|c|}{ H } & \multicolumn{1}{|c|}{ DD } \\
\hline $\mathbf{1}$ & Days to 50\% flowering & $180.89 * *$ & 0.00 & 0.00 \\
\hline $\mathbf{2}$ & Days to maturity & $236.00^{* *}$ & $19.11^{*}$ & 0.28 \\
\hline $\mathbf{3}$ & Plant height & $4990.78^{* *}$ & 552.56 & 0.33 \\
\hline $\mathbf{4}$ & Green fodder yield & 0.00 & $125463.56^{* *}$ & 0.00 \\
\hline $\mathbf{5}$ & Dry fodder yield & $36144.78^{* *}$ & $75153.44 * *$ & 1.44 \\
\hline $\mathbf{6}$ & Ear head length & $22.70^{*}$ & 10.90 & 0.69 \\
\hline $\mathbf{7}$ & Number of primaries per plant & $1324.60^{* *}$ & $691.78^{* *}$ & 0.72 \\
\hline $\mathbf{8}$ & Number of seeds per primary & $6041.64 * *$ & $2192.76^{* *}$ & 0.60 \\
\hline $\mathbf{9}$ & Seed index & 0.16 & $0.32 *$ & 1.40 \\
\hline $\mathbf{1 0}$ & Harvest index & $399.93 * *$ & $451.31 * *$ & 1.06 \\
\hline $\mathbf{1 1}$ & Grain yield & $7983.53 * *$ & $8097.93 * *$ & 1.01 \\
\hline $\mathbf{1 2}$ & Protein content in grain & $8.65 * *$ & $6.01 * *$ & 0.83 \\
\hline $\mathbf{1 3}$ & Protein content in fodder & $10.36^{* *}$ & $5.03 * *$ & 0.70 \\
\hline
\end{tabular}


Table.5 D and H components with and without epistatic lines

\begin{tabular}{|c|c|c|c|c|c|c|c|c|c|c|}
\hline \multirow{2}{*}{$\begin{array}{l}\text { S. } \\
\text { No. }\end{array}$} & \multirow[t]{2}{*}{ Character } & \multirow[t]{2}{*}{ Cross } & \multirow[t]{2}{*}{ Epitasis } & \multirow{2}{*}{$\begin{array}{c}\text { No of } \\
\text { epistatic lines }\end{array}$} & \multicolumn{3}{|c|}{ All lines } & \multicolumn{3}{|c|}{ Without epistatic lines } \\
\hline & & & & & D & $\mathbf{H}$ & H/D & D & $\mathbf{H}$ & H/D \\
\hline \multirow[t]{2}{*}{1} & \multirow[t]{2}{*}{ Days to $50 \%$ flowering } & $\mathrm{A} \times \mathrm{C}$ & $231.97 *$ & 3 & $321.45^{* *}$ & $93.04 *$ & 0.54 & $367.81 * *$ & $81.56^{* *}$ & 0.47 \\
\hline & & $\mathrm{B} \times \mathrm{C}$ & $603.07 * *$ & 6 & $334.06 * *$ & $191.27 * *$ & 0.76 & $180.89 * *$ & $14.28 * *$ & 0.28 \\
\hline \multirow[t]{2}{*}{2} & \multirow[t]{2}{*}{ Days to maturity } & $A \times C$ & $97.00 * *$ & 6 & $126.89 * *$ & $25.50 * *$ & 0.45 & $351.78 * *$ & $9.94 * *$ & 0.17 \\
\hline & & $\mathrm{B} \times \mathrm{C}$ & $184.70^{* *}$ & 7 & $103.08 * *$ & $29.33 * *$ & 0.53 & $236.00 * *$ & $37.33^{* *}$ & 0.40 \\
\hline \multirow[t]{2}{*}{3} & \multirow[t]{2}{*}{ Plant height } & $\mathrm{A} \times \mathrm{C}$ & $10609.40 * *$ & 1 & $3163.16^{* *}$ & $3863.04 * *$ & 1.11 & $3630.56^{* *}$ & $5629.59 * *$ & 1.25 \\
\hline & & $\mathrm{B} \times \mathrm{C}$ & $9583.77 * *$ & 6 & $4975.14 * *$ & $920.77 *$ & 0.43 & $4990.78 * *$ & $2085.50 * *$ & 0.65 \\
\hline \multirow[t]{2}{*}{4} & \multirow[t]{2}{*}{ Green fodder yield } & $\mathrm{A} \times \mathrm{C}$ & $322890.13^{* *}$ & 3 & $187193.45^{* *}$ & $57100.71 * *$ & 0.55 & $134389.68 * *$ & $34047.52 * *$ & 0.50 \\
\hline & & $\mathrm{B} \times \mathrm{C}$ & $191630.97 * *$ & 7 & $154350.64 * *$ & $117187.61 * *$ & 0.87 & 0.00 & $136301.33 * *$ & 0.00 \\
\hline \multirow[t]{2}{*}{5} & \multirow[t]{2}{*}{ Dry fodder yield } & $\mathrm{A} \times \mathrm{C}$ & $81064.20 * *$ & 4 & $47004.10 * *$ & $24548.07 * *$ & 0.72 & $36693.33^{* *}$ & $14635.42 * *$ & 0.63 \\
\hline & & $\mathrm{B} \times \mathrm{C}$ & $75785.50 * *$ & 6 & $27360.50 * *$ & $33715.76^{* *}$ & 1.11 & $36144.78^{* *}$ & $77970.78^{* *}$ & 1.47 \\
\hline \multirow[t]{2}{*}{6} & \multirow[t]{2}{*}{ Ear head length } & $\mathrm{A} \times \mathrm{C}$ & 34.67 & 0 & 7.10 & $59.42 *$ & 2.89 & 7.10 & $85.57 * *$ & 3.47 \\
\hline & & $\mathrm{B} \times \mathrm{C}$ & $238.37 * *$ & 0 & $22.70^{*}$ & 10.90 & 0.69 & $22.70 *$ & $45.76^{* *}$ & 1.42 \\
\hline \multirow[t]{2}{*}{7} & \multirow{2}{*}{$\begin{array}{l}\text { Number of primaries / } \\
\text { plant }\end{array}$} & $\mathrm{A} \times \mathrm{C}$ & $1628.57 * *$ & 3 & $1600.68 * *$ & $191.56^{* *}$ & 0.35 & $1188.32 * *$ & $301.06 * *$ & 0.50 \\
\hline & & $\mathrm{B} \times \mathrm{C}$ & $1717.63 * *$ & 3 & $1076.67 * *$ & $961.64 * *$ & 0.95 & $1324.60 * *$ & $1089.16^{* *}$ & 0.91 \\
\hline \multirow[t]{2}{*}{8} & \multirow{2}{*}{$\begin{array}{l}\text { Number of seeds / } \\
\text { primary }\end{array}$} & $\mathrm{A} \times \mathrm{C}$ & $1955.23 * *$ & 3 & $1957.05^{* *}$ & $818.27 * *$ & 0.65 & $2052.16^{* *}$ & $865.83 * *$ & 0.65 \\
\hline & & $\mathrm{B} \times \mathrm{C}$ & $5935.90 * *$ & 4 & $5104.09 * *$ & $2576.03 * *$ & 0.71 & $6041.64 * *$ & $4782.60 * *$ & 0.89 \\
\hline \multirow[t]{2}{*}{9} & \multirow[t]{2}{*}{ Seed index } & $\mathrm{A} \times \mathrm{C}$ & $1.71 * *$ & 2 & $0.55 * *$ & $0.47 * *$ & 0.93 & $0.53 *$ & $0.75 * *$ & 1.19 \\
\hline & & $\mathrm{B} \times \mathrm{C}$ & 1.06 & 3 & 0.10 & $0.31 * *$ & 1.72 & 0.16 & $0.39 * *$ & 1.54 \\
\hline \multirow[t]{2}{*}{10} & \multirow[t]{2}{*}{ Harvest index } & $\mathrm{A} \times \mathrm{C}$ & 54.08 & 1 & $114.29 * *$ & 29.10 & 0.50 & $127.72 * *$ & $81.43 * *$ & 0.80 \\
\hline & & $\mathrm{B} \times \mathrm{C}$ & $1240.86 * *$ & 3 & $783.75 * *$ & $509.07 * *$ & 0.81 & $399.93 * *$ & $547.71 * *$ & 1.17 \\
\hline \multirow[t]{2}{*}{11} & \multirow[t]{2}{*}{ Grain yield } & $\mathrm{A} \times \mathrm{C}$ & $13097.93 * *$ & 3 & $6938.61 * *$ & $2516.56^{* *}$ & 0.60 & $8926.16^{* *}$ & $2464.76^{* *}$ & 0.53 \\
\hline & & $\mathrm{B} \times \mathrm{C}$ & $21487.23^{* *}$ & 5 & $15337.33^{* *}$ & $10361.63 * *$ & 0.82 & $7983.53 * *$ & $8377.13 * *$ & 1.02 \\
\hline \multirow[t]{2}{*}{12} & Protein content in grain & $\mathrm{A} \times \mathrm{C}$ & $98.29 * *$ & 0 & $20.65 * *$ & $10.87 * *$ & 0.73 & $20.65 * *$ & $12.99 * *$ & 0.79 \\
\hline & & $\mathrm{B} \times \mathrm{C}$ & $72.00 * *$ & 5 & $13.25 * *$ & $21.13 * *$ & 1.26 & $8.65 * *$ & $13.46 * *$ & 1.25 \\
\hline 13 & Protein content in fodder & $\mathrm{A} \times \mathrm{C}$ & $16.32 * *$ & 4 & $6.96 * *$ & $2.69 * *$ & 0.62 & $10.78 * *$ & $4.24 * *$ & 0.63 \\
\hline & & $\mathrm{B} \times \mathrm{C}$ & $15.58 * *$ & 5 & $6.46^{* *}$ & $2.96 * *$ & 0.68 & $10.36 * *$ & $5.56^{* *}$ & 0.73 \\
\hline
\end{tabular}

$*$, ** Significant at 5 and 1 percent level of significance, respectively 
In the presence of epistasis, the estimates D (additive variance) and $\mathrm{H}$ (dominance variance) are biased. To estimate unbiased $\mathrm{D}$ and $\mathrm{H}$ the triple test cross was used. Further, plant population per unit area is a major factor affecting the production of the crop. Most desirable genotype is one having buffering ability to cop up the yield under varying plant populations. Accordingly, to identify such genotype different spacing was used and $\mathrm{G} x$ $\mathrm{E}$ interaction was studied. To identify potential crosses along with nature of inheritance present investigation was planned to generate information about nature of inheritance. To generate the above information triple Test Cross Analysis is the best mating design for unbiased estimation of $\mathrm{D}$ and $\mathrm{H}$ components.

The line $\mathrm{x}$ tester analysis was based on fixed effect model therefore estimation of additive and dominant variance were not possible further estimation $\mathrm{D}$ and $\mathrm{H}$ component having biased estimation in two factor mating design. The triple test cross analysis proposed by Ketataa (1976) provide unbiased estimation of $\mathrm{D}$ and $\mathrm{H}$ components.

In present investigation difference between test crosses in lines were significant for all the characters in both the set (SPV 245 X SPV 1822 and SPV $1430 \mathrm{x}$ SPV 1822) except harvest index in set SPV 245 x SPV 1822. This indicates presence of variability in test crosses in lines.

In case of unbiased estimation, the magnitude of $\mathrm{D}$ and $\mathrm{H}$ may change in any direction accordingly the degree of dominance may also changed. The cross SPV 245 x SPV 1822 (33) cross was least epistatic i.e. out of 130 combinations (10 lines $\mathrm{x} 13$ characters $)$ epistasis was significant in 33 . The ear head length was followed by harvest index (4), seed index (5), protein content in grain (5), number of primaries per plant (6), number of seeds per primary (7) and protein content in fodder (9). In these lines in three testers epistasis was present in less than 10 combinations. The lines depicted medium epistasis in cross SPV 1430 x SPV 1822 (60) followed by SPV 245 x SPV 1822 (33). Among the lines were having epistasis for one character only in cross SPV 1430 x SPV 1822 $\left(\mathrm{L}_{2}\right)$, SPV 245 x SPV $1822\left(\mathrm{~L}_{8}\right)$.

The total epistasis was significant for all the characters in both the crosses except ear head length and harvest index in SPV 245 X SPV 1822, seed index in SPV 1430 x SPV 1822. In both the crosses the $\mathrm{j}+1$ type of epistatisis was also significant. The additive $\mathrm{x}$ additive (i) epistasis was more frequent in set SPV 1430 x SPV1822 where it significant for eight characters. In set SPV 245 x SPV1822 it was significant for 3 characters. It was significant in both the sets for protein content in grain, ear head length, dry fodder yield. This indicates the present of epistasis and need to unbiased estimation of $\mathrm{D}$ and $\mathrm{H}$ components. The significance of epistastic effect further tested for each line, none of the line exhibited significant epistasis for ear head length.

The other characters having less epistatic lines were harvest index, seed index, protein content in grain, number of primaries per plant, number of seeds per primary and protein content in fodder. In cross SPV 1430 x SPV 1822 maximum epistasis was observed considering different crosses and different characters, it was followed by SPV $245 \mathrm{X}$ SPV 1822.

After dropping the epistatic lines unbiased D and $\mathrm{H}$ were estimated. This indicates that epistasis may bias the $\mathrm{D}$ and $\mathrm{H}$ components in any direction and average degree of dominance may change accordingly (Table 5). The unbiased estimation revealed significance of $\mathrm{D}$ and $\mathrm{H}$ components for all the characters in both the crosses except 
additive variance (D) for green fodder yield and seed index in SPV 1430 x SPV 1822, ear head length in SPV 245 X SPV 1822. The total epistasis was also absent in all the above exceptional sets for above characters. This indicates that significance of epistasis more biased the $\mathrm{D}$ in present investigation.

The average degree of dominance for number of seeds per primary, number of primary per plant, protein content in grain and protein content in fodder was less than one and for seed index the degree of dominance was more than one. For rest of the characters it was varied from set to set.

The crosses having economic heterosis for grain yield having significance of epistasis in one or other set similarly the crosses having economic heterosis for dry fodder yield also following the same trend. As the environmental conditions in which the hybrids showing economic heterosis for grain yield and dry fodder yield was different than the crosses evaluated for triple test cross therefore, in the absence of uniform trend in different environments and crosses we cannot use this information directly in the exploitation of crosses having economic heterosis for grain yield and dry fodder yield. Similar results for one or more characters were also obtained by Singh et al., (1991), Kashyap and Rastogi (2006), Singh et al., (2006), Sood et al., (2007), Meena et al., (2017) and Meena et al., (2018, 2020).

\section{Acknowledgements}

Indian Council of Agricultural Research (ICAR), is sincerely acknowledged for financial support of the study, Maharana Pratap University of Agriculture and Technology (MPUAT) is sincerely acknowledged for providing facility and support for the study.

\section{References}

Anonymous 2015. FAOSTAT, Food and Agriculture Organization of the United Nations Statistics Division, Rome.

Bahadure DM, Marker S, Umakanth AV, Prabhakar, Ramteke PW, Patil JV and Rana BS (2015) Combining ability and heterosis on millable stalk and sugar concentration for bioethanol production across environments in sweet sorghum (Sorghum bicolor (L.) Moench). Electronic Journal of Plant Breeding 6: 58-65.

Bhadouriya, N. S. and Saxena, M. K. (1997). Combining ability studies in sorghum through diallel analysis. Crop Res., 14(2): 253-256.

Bunphan D, Jaisil P, Sanitchon J, Knoll JE and Anderson WF (2015) Heterosis and combining ability of F1 hybrid sweet sorghum in Thailand. Crop Science 55: 178-187.

Daljit Singh. 1979. Diallel analysis for combining ability over environments. Indian J. Genet., 39(3): 383-386.

Bhavsar, V. V. and Borikar, S. T. (2002). Combining ability studies in sorghum involving diverse cytosteriles. J. Maharashtra Agric. Univ., 27(1): 35-38.

Chaudhary, S.B., Patil, J.V., Thombare, B.B. and Kulkarni, V.M. (2004). Selection of parents based on combining ability in sorghum [Sorghum bicolor L. Moench]. Annals of Plant Physiology 20 (1): 95-97.

Doggett H, 1988. Sorghum. Longman Scientific \& Technical, London. Cereal Sci 44: 236251

Fisher, R. A. (1932). The Genetical Theory of Natural Selection. Clarendon, Oxford.

Griffing, B. (1956). Concept of general and specific combining ability in relation to diallel crossing system. Aust. J. Biol. Sci., $9:$ 463-493.

Iyanar, K., Gopalan, A. and Ramasamy, P. (2001). Combining ability analysis in sorghum [Sorghum bicolor (L.) Moench]. Annals of Agriculture Research New Series, 22 (3): 341-345.

Indhubala M, Ganesamurthy $\mathrm{K}$ and Punitha D (2010) Combining ability studies for quality traits in Sweet Sorghum (Sorghum 
bicolor (L.) Moench). The Madras Agricultural Journal 97: 17-20.

Karale, M. U, Suryavanshi, Y. B. and Mehtre, S. S. (1998). Combining ability studies in sorghum (Sorghum bicolor (L.) Moench). Andhra Agric. J., 45: 42-46.

Kaul, S. L., Rafiq, F. M. and Singh, K. (2003). Heterobeltiosis and combining ability for grain yield components in post rainy season sorghum. International Sorghum and Millets News Letter, 44: 21-23.

Leonilo V. Gramaje. Joanne D. Caguiat. John Oscar S. Enriquez. Quirino D. dela Cruz. Reneth A. Millas. Jake E. Carampatana .Dindo Agustin A. Tabanao. (2020).Heterosis and combining ability analysis in CMS hybrid rice. Euphytica 216:14.

Mara Jane da Rocha1, José Airton Rodrigues Nunes, Rafael Augusto da Costa Parrella, Pakizza Sherma da Silva Leite, Gabrielle Maria Romeiro Lombardi, Mayra Luiza Costa Moura, Robert Eugene Schaffert and Adriano Teodoro Bruzi (2018). General and specific combining ability in sweet sorghum. Crop Breeding and Applied Biotechnology, 18:365-372.

Meena B.L., B.R. Ranwah, S.P. Das, S.K. Meena, R. Kumari, Rumana Khan, V.K. Bhagasara and A. Gangarani Devi (2017). Estimation of Heterosis, Heterobeltiosis and Economic Heterosis in Dual Purpose Sorghum [Sorghum bicolor (L.) Moench]. Int.J.Curr.Microbiol.App.Sci. 6(5): 9901014

Meena B.L., Ranwah, B.R., Das S.P., Meena H S, Meena, S.K., Kumari R. and Nath, Anamika (2018). Assessment of Economic Heterosis in Dual Purpose Sorghum [Sorghum bicolor (L.) Moench]. Int.J. Curr.Microbiol. App.Sci 7(7):3196-3205.
Meena B.L., B.R. Ranwah, H.S. Meena, M.D. Meena, K.N. Meena and P.K. Rai (2020). Stability Analysis in Dual Purpose Sorghum [Sorghum bicolor (L.) Moench]. Int.J.Curr.Microbiol.App.Sci. 9(03): 25212530.

Pillai, M.A., Rangaswamy, P., Nadarjan, N., Vannirajan, C and Ramalingam, J. (1995). Combining ability analysis for ear head characters in sorghum. Indian Journal of Agricultural Research, 29 (2): 98-102.

Patel, S. D., Patel, A. I., Patel, R. H., Mali, S. C., Patel, V. S. and Kshirsagar, R.M. (2006). Study of heterosis in sorghum. Crop Prot. Prod., 2(2): 59-63.

Rafiq, S. M., Thete, R. Y., Madhusudhana, R. and Umakanth, A. V. (2002). Combining ability studies for grain yield and its components in post rainy season where sorghum grown in medium deep and shallow soils. International Sorghum and Millet News Letter, 43: 33-37.

Ravindrababu, Y., Pathak, A. R. and Tank, C. J. (2001). Studies on combining ability for yield and yield attributes in sorghum (Sorghum bicolor (L.) Moench). Crop Res., 22 (2): 274-277.

Salunke, C. B. and Deore, G. N. (2000). Combining ability studies for physiological traits, harvest index and grain yield in rabi sorghum. Ann. Plant Physiol., 14 (2): 190195.

Thakare, D.P., Ghorade, R. B and Bagade A.B. (2014). Combining ability studies in Grain Sorghum using line $\mathrm{X}$ tester analysis. Int.J. Curr.Microbiol. App.Sci 3(10) 594-603.

Yadav, R .and Pahuja, S.K. (2007). Combining ability for fodder yield and its components in forage sorghum. Forage Research, 32 (4): $220-223$.

\section{How to cite this article:}

Meena, B. L., B. R. Ranwah, H. S. Meena and Meena, M. D. 2020. Nature of Inheritance of Yield and its Related Traits in Dual Purpose Sorghum [Sorghum bicolor (L.) Moench]. Int.J.Curr.Microbiol.App.Sci. 9(09): 882-895. doi: https://doi.org/10.20546/ijcmas.2020.909.110 